\title{
Abundance and species richness of overwintering ground beetles (Coleoptera: Carabidae) are higher in the edge than in the centre of a woodlot
}

\author{
Anthony ROUME ${ }^{1}$, ANNIE OUIN $^{2}$, LAURENT RAISON ${ }^{1}$ and MarC DECONCHAT ${ }^{1}$ \\ ${ }^{1}$ INRA, UMR 1201 Dynafor, INRA / INP-ENSAT / INP-EIPurpan, BP 52627, F-31326 Castanet Tolosan, France; \\ e-mails: anthony.roume@toulouse.inra.fr; laurent.raison@toulouse.inra.fr; marc.deconchat@toulouse.inra.fr \\ ${ }^{2}$ Université de Toulouse, UMR 1201 Dynafor, INRA / INP-ENSAT / INP-EIPurpan, BP 32607, 31326 Castanet Tolosan, France; \\ e-mail: ouin@ensat.fr
}

Key words. Beneficial arthropods, Coleoptera, Carabidae, hibernation, emergence trap, woodlot, boundary, edge, logging

\begin{abstract}
Semi-natural habitats are key components of rural landscapes because they shelter a significant number of overwintering arthropods that are beneficial to agriculture. However, woodlots are semi-natural habitats with high patch-level heterogeneity and this aspect has been poorly studied. The purpose of this study was to determine the influence of woodlot heterogeneity on overwintering ground beetles. Woodlot heterogeneity was characterized in terms of distance from the woodlot boundary and date of the most recent logging operation. We used emergence traps to quantify the population density of ground beetles that overwintered in the different parts of the woodlot. In woodlot edges the densities and species richness of ground beetles were significantly higher than in the rest of the woodlot. Ground beetles that are active in crop fields overwintered in the edges but not in the inner zone of the woodlot. Species assemblages of ground beetles overwintering in the edges were highly diverse. The date of the most recent logging operation did not explain the distribution of ground beetles that overwintered in the woodlot. Our results show that woodlots, and in particular their edges, are used as a winter shelter by ground beetles that spend part of their life in crops, which potentially favours biological control in adjacent crop fields.
\end{abstract}

\section{INTRODUCTION}

Agriculture is benefitted by the many arthropods that feed on pests and seeds of weeds. Although these arthropods feed in particular in crops and grasslands and provide some ecological services, they overwinter extensively in semi-natural habitats like hedges, ditches or grassy field margins (e.g. Sotherton, 1984; Pfiffner \& Luka, 2000; Geiger et al., 2009). These habitats have a more buffered micro-climate, are less subject to agricultural disturbance, and provide complementary and alternative food resources for larvae and adults (Bianchi et al., 2006). Investigating the role of such habitats as refuges for beneficial arthropods will contribute to the development of integrated pest management using landscape engineering (Landis et al., 2000).

Among arthropods, ground beetles (Coleoptera: Carabidae) are reported to play a major role in pest control because they are abundant in crop fields, and many are polyphagous predators that are present at the beginning of the development of pest populations, when their service of regulation is assumed to be the most efficient (Kromp, 1999; Sunderland, 2002; Symondson et al., 2002). Other species of ground beetles are phytophagous and contribute to the control of weed populations by feedind on the seeds of weeds, even if some of these species also damage crops (Kromp, 1999; Tooley \& Brust, 2002; Honek et al., 2003).

There are many studies on overwintering of ground beetles and other beneficial arthropods in field margins, like grassy margins or hedges (Andersen, 1997; Pfiffner
\& Luka, 2000; Pywell et al., 2005) and beetle banks (Thomas et al., 1992) but few have looked at woodlots as potential overwintering sites (Sotherton, 1984; Yamazaki et al., 2002; Geiger et al., 2009), and only Yamazaki et al. (2002) explicitly studied the distribution of overwintering ground beetles in forests. However, it is noteworthy that in temperate rural landscapes, wooded areas can represent as much as $30 \%$ of the landscape and include a high proportion of small woodlots (du Bus de Warnaffe et al., 2006). Woodlots adjacent to crop fields are likely to play an important role as a refuge for overwintering ground beetles at the landscape scale. Moreover, woodlots are heterogeneous habitats as they are affected by edge effects (Murcia, 1995) and by logging operations whose influence decreases in the course of time. This heterogeneity is particularly noticeable in the small woodlots managed by farmers that are common in rural landscapes (du Bus de Warnaffe et al., 2006) and leads to disparate conditions at the woodlot scale in terms of micro-climate, soil structure, vegetation composition and structure and biotic interactions (Deconchat, 2001). Overwintering ground beetles are known to be influenced by these factors (Dennis et al., 1994; du Bus de Warnaffe \& Dufrêne, 2004; Pywell et al., 2005) and their activity-density and/or species richness are higher in the edges of woodlots and in recently logged zones than in the rest of woodlots due to the presence of generalist or open habitat species (Jukes et al., 2001; Magura, 2002).

In the present study, emergence traps were used to determine whether the densities of ground beetles overwintering in different parts of a woodlot are dependent on 
the distance to the edge of the woodlot and date of the most recent logging operation. We tested the hypotheses (i) that there was a higher abundance and species richness of ground beetles overwintering in the edges than in the inner zone of the woodlot and in recently logged zones than in zones logged a long time ago and (ii) that open habitat species of ground beetles are more abundant in the edges of the woodlot and in recently logged zones than in the rest of the woodlot.

\section{MATERIAL AND METHODS}

\section{Site}

The study was carried out in the long-term socio-ecological research platform (LTSER) "Valleys and Hills of Gascogny". This rural region of south-western France $\left(43^{\circ} 16^{\prime} \mathrm{N}, 0^{\circ} 51^{\prime} \mathrm{E}\right)$ is hilly (250-400 $\mathrm{m}$ asl.) and has a sub-Atlantic climate with mountain and slight Mediterranean influences (mean annual temperature $12.5^{\circ} \mathrm{C}$ and mean annual precipitation $750 \mathrm{~mm}$ ). The forest in this area is fragmented into woodlots with areas ranging from 0.5 to $20 \mathrm{ha}$, and the total forest cover in the landscape is around $25 \%$. Woodlot edges are several decades old and are regularly pruned by farmers.

Since it is difficult to obtain detailed data on the history of logging in such small woodlots, we decided to focus our study on one very well-known woodlot, large enough (11 ha) to be heterogeneous in terms of logging history and not too large to reduce other sources of heterogeneity, such as soil. The woodlot selected was representative of the site with respect to area, vegetation composition (dominated by Quercus robur and Q. pubescens) and management (coppice with standing trees). It was surrounded by grassland and a stream (east facing edge), a winter wheat field (south facing edge), a fallow area (north facing edge) and a fallow area separated from the woodlot by a road (west facing edge).

\section{Ground beetles}

In the woodlot, we set up a large number of emergence traps (four per ha) in order to obtain a detailed view of the spatial distribution of the beetles. An emergence trap was set up in each of 45 locations defined according to two stratification factors assumed to influence the distribution of ground beetles: the distance from woodlot boundary and the date of the most recent logging operation. The boundary of the woodlot was defined as the line joining the bases of the first trees (diameter at $1.3 \mathrm{~m}>10 \mathrm{~cm}$ ) belonging to the woodlot. We selected three separate zones in the woodlot according to their distance from the boundary: the edge zone $(0 \mathrm{~m}$ to $3 \mathrm{~m}$ from the boundary of the woodlot on the woodlot side), the centre ( $75 \mathrm{~m}$ to $100 \mathrm{~m}$ from the boundary) and an intermediate zone ( $25 \mathrm{~m}$ to $50 \mathrm{~m}$ from the boundary). The sequence and spatial extent of logging between 1938 and 2003 was determined for the inner zones of the woodlot (not the edges) from aerial photographs and interviews with the owners (du Bus de Warnaffe et al., 2006). This information was used to determine four periods of logging in the woodlot. Twelve traps were placed in the edge zone of the woodlot and between 3 to 5 traps were placed in each of the eight zone $\mathrm{X}$ period combinations in the inner part of the woodlot (Table 1).

We chose emergence traps to sample ground beetle assemblages because they can be used to estimate the population densities of overwintering insects in very limited areas. Moreover, they have the advantage of primarily capturing adults, which are easier to identify than larvae caught when sampling soil and litter. Each trap consisted of a $1.8 \mathrm{~m}^{2}$ tent made of $0.5 \mathrm{~mm}$ mesh, with the sides buried in the soil to a depth of $10 \mathrm{~cm}$ to prevent insects from moving in or out of the tent. Each emergence trap included two receptacles for catching insects: an upper receptacle half-filled with $70 \%$ ethanol at the top of the mesh tent to catch flying and climbing insects and a lower receptacle, the opening of which was level with the soil surface, containing a solution of $50 \%$ propylene-glycol and placed in one corner of the tent to catch epigeous arthropods. Emergence traps were set in late February and the receptacles were collected once a month from late February to late October 2008.

Ground beetles were identified to species level using morphological keys (Jeannel, 1942; Hurka, 1996). We summed abundances of ground beetles in the two receptacles in each trap over the whole trapping period and used the number of each species of ground beetle per trap in the analysis. Information on the habitats where adults of ground beetles are mainly active came from previous studies based on pitfall trap catches or direct observations (Jeannel, 1942; Thiele, 1977; Luff, 2002; Pizzolotto et al., 2005) and data previously obtained at the study site (unpubl. data). The following nomenclature was used: species whose adults are active in forests, woodlots and/or hedges are called "woody habitat species"; species whose adults are active in crop fields and/or grasslands are called "open habitat species"; species whose adults are equally active in both types of habitats are called "generalist species". Eight species out of 48 could not be attributed to any of the groups because of lack of information, but represented less than $1 \%$ of the total number of individuals (see the Appendix).

\section{Analysis}

First, we assessed whether or not the abundance and/or species richness of ground beetles was higher in the edges of the woodlot and in recently logged zones than in the two inner zones and in previously logged zones in the woodlot. The effect of each factor (distance from the boundary and date of the most recent logging) was evaluated separately by comparing the abundance and then the species richness in the different classes for each factor. The residues of abundance or species richness did not follow a normal distribution after comparison of the means in the different zones. Thus, this comparison was done using non parametric Wilcoxon rank tests, including BenjaminiHochberg correction of $P$-values to cope with the increased false-positive detection due to the multiplicity of tests (Benjamini \& Hochberg, 1995). Then, the same method was used to determine the effect of the distance from the boundary on the density of the three groups of ground beetles described above.

TABLE 1. Number of emergence traps in the different zones of the woodlot based on two stratification factors: distance from the boundary (rows) and date of the most recent logging (columns).

\begin{tabular}{ccccccc}
\hline & \multicolumn{5}{c}{ Date of the most recent logging } \\
\cline { 3 - 7 } & & Before 1938 & $1938-1959$ & $1960-1981$ & $1982-2003$ & Total \\
\hline \multirow{3}{*}{ Distance from } & Edge & - & - & - & - & 12 \\
the boundary & Intermediate & 4 & 4 & 5 & 3 & 16 \\
& Centre & 5 & 3 & 4 & 5 & 17 \\
\hline
\end{tabular}


A

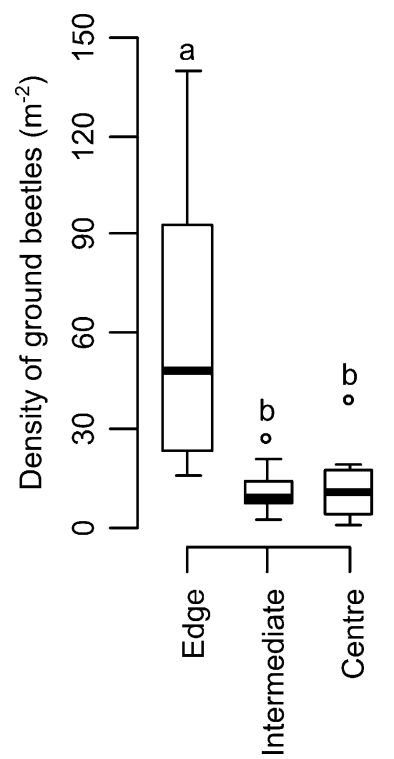

B

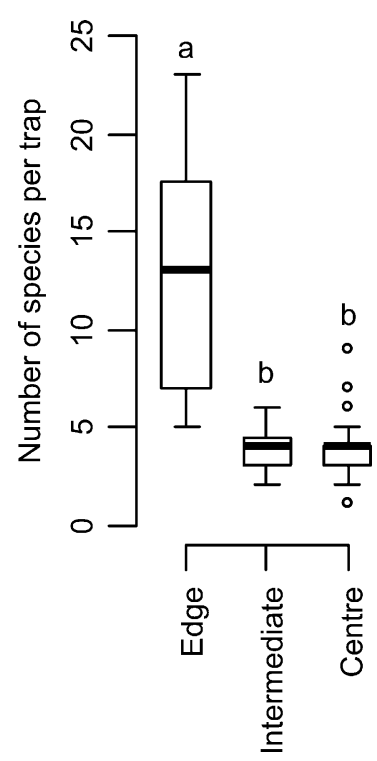

Fig. 1. Density (A) and species richness (B) of ground beetles in zones of the woodlot at different distances from the boundary. The thick line represents the median, the limits of the boxes the $25 \%$ and the $75 \%$ quantiles and the limits of the whiskers the $10 \%$ and $90 \%$ quantiles. Outliers are plotted as dots. Different letters above the boxes indicate significant differences based on a Wilcoxon rank test including the Benjamini-Hochberg correction $(\mathrm{P}<0.05)$.

All the analyses were performed using $\mathrm{R}$ software version 2.11.1 (R Development Core Team, 2010).

\section{RESULTS}

\section{Spatial distribution of ground beetles in the woodlot}

We collected 2014 ground beetles belonging to 48 species during the whole trapping period. Significantly more individuals were caught in the edges than in the inner zones of the woodlot (Edge vs. Intermediate zone: Wilcoxon rank test $W=186, P<0.001$; Edge vs. Centre: $W=15.5, P<0.001)$. The catches in the edges of the woodlot indicated a median of 47.5 ground beetles per square meter (density in traps ranged from 16 to 140 ground beetles per square meter), whereas the median was respectively of 8.9 and 10.6 ground beetles per square meter in the intermediate zone and in the central zone of the woodlot (density in traps ranged from 1 to 38 ground beetles per square meter, Fig. 1A). Species richness was also significantly higher in the edges than in the two inner zones of the woodlot (Fig. 1B; Edge vs. Intermediate zone: $W=187, P<0.001$; Edge vs. Centre: $W=10.5, P<0.001)$ with a median number of species per trap of 13 and values ranging from 5 to 23 species per trap in the edges compared to a median number of species per trap of 4 in the intermediate zone and in the central zone of the woodlot (values ranging from 1 to 9 species per trap).

In the inner part of the woodlot, zones logged at different periods did not differ significantly in terms of density (Fig. 2A) and species richness (Fig. 2B) of overwintering ground beetles.

A
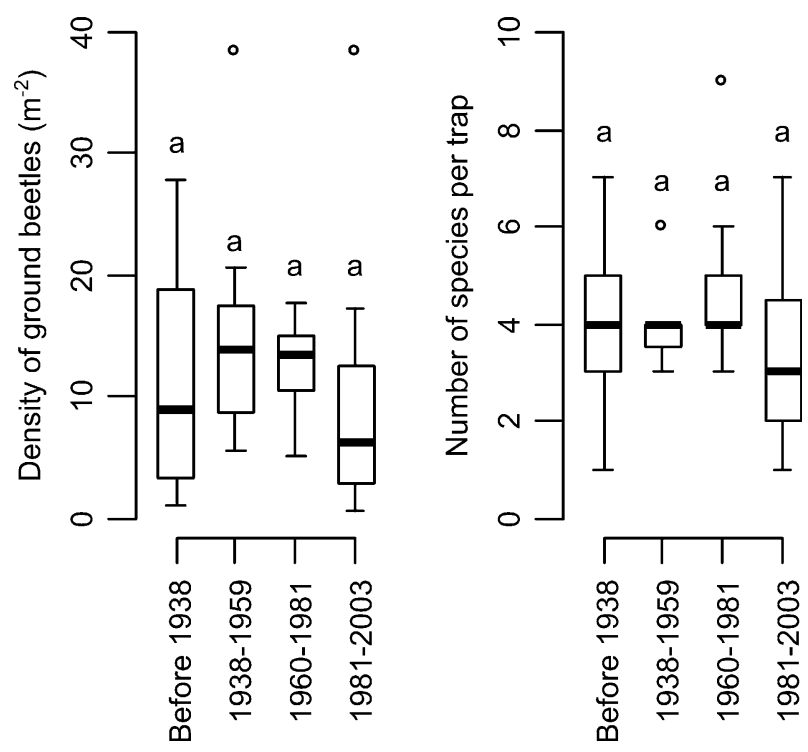

Fig. 2. Density (A) and species richness (B) of ground beetles in zones of the woodlot that differed in when they were last logged. The thick line represents the median, the limits of the boxes the $25 \%$ and the $75 \%$ quantiles and the limits of the whiskers the $10 \%$ and $90 \%$ quantiles. Outliers are plotted as dots. Different letters above the boxes indicate significant differences based on a Wilcoxon rank test including the Benjamini-Hochberg correction $(\mathrm{P}<0.05)$.

\section{Species assemblages of ground beetles in the edges and the inner part of the woodlot}

Abax paralellepipedus Piller \& Mitterpatcher, Pterostichus madidus Fabricius and Carabus auratus Linnaeus, which are woody habitat species at the site studied, were the dominant species in terms of density in the two inner zones of the woodlot (Fig. 3). Overwintering individuals of 17 other species were also found in the inner zone of the woodlot.

The remaining 28 species were found to overwinter only in the edges of the woodlot. Most of these species were open habitat species, like the most abundant species: Syntomus obscuroguttatus Duftschmidt, Anchomenus dorsalis Pontoppidan and Demetrias atricapillus Linnaeus.

\section{Influence of the distance from the boundary on the density of generalist species and species associated with woody or open habitats}

There was a significantly higher density of open habitat species in the edges than in the two inner zones of the woodlot, where their densities were nearly zero (Fig. 4; Edge vs. Intermediate zone: $W=183.5, P<0.001$; Edge vs. Centre: $W=17, P<0.001)$. Generalist species showed exactly the same pattern as open habitat species (Edge vs. Intermediate zone: $W=172, P<0.001$; Edge vs. Centre: $W=24.5, P<0.001)$. The density of woody habitat species was also significantly greater in the edges than in the inner zone of the woodlot as a whole $(W=282$, $P=0.032$ ) but the differences between the densities in the edges and either the centre or the intermediate zone were 


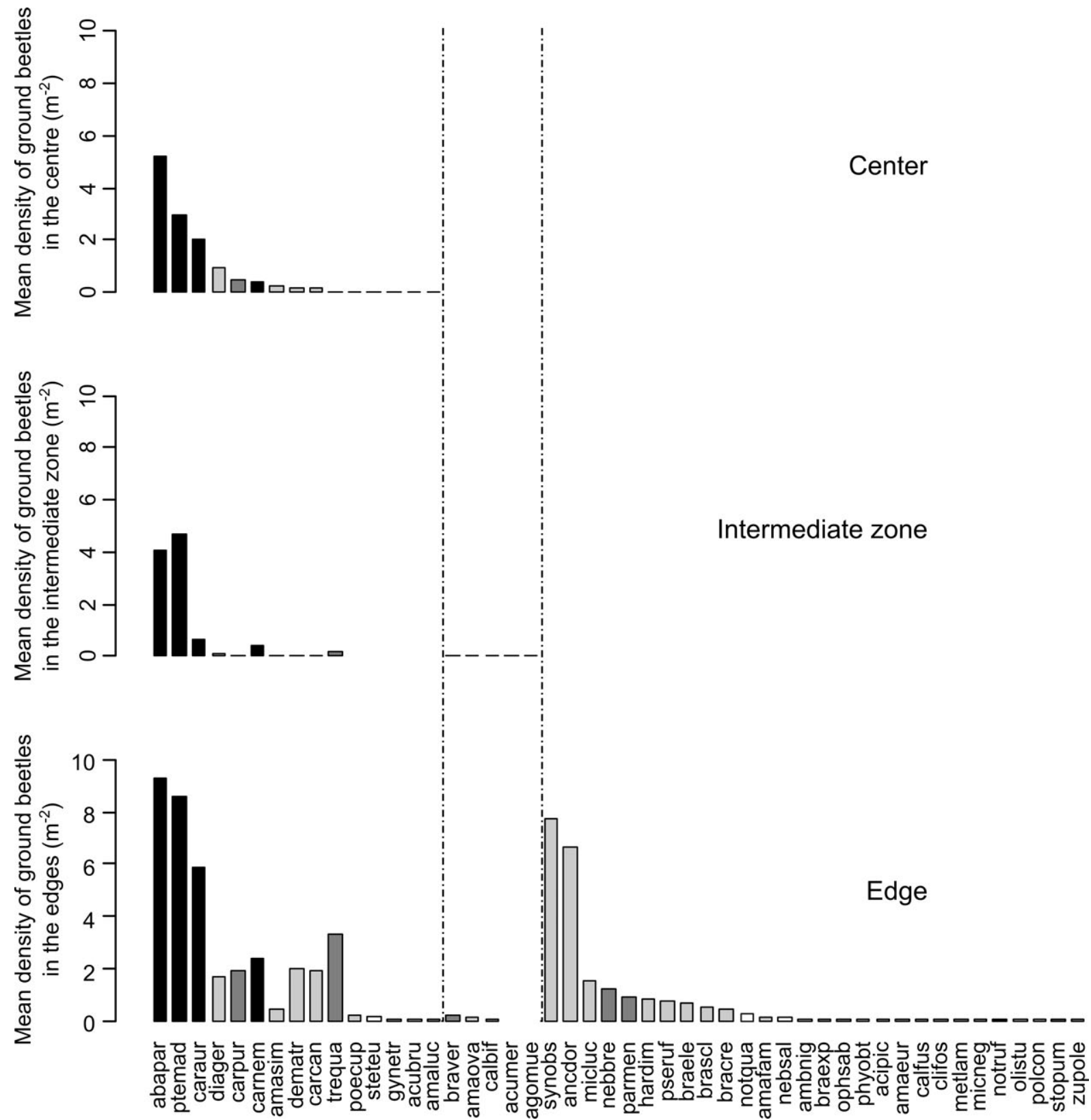

Fig. 3. Mean density of the 48 species in the central (upper graph), intermediate (middle graph) and edge (lower graph) zones of the woodlot. Species are ordered by each of three criteria: first by abundance in the central zone, then by abundance in the intermediate zone and finally by abundance in the edges of the woodlot. Vertical lines show delimitations between species present in the different zones. Black, dark gray and light gray bars indicate woody habitat, generalist and open habitat species, respectively. The species codes and their full names are listed in the Appendix.

not significant (Edge vs. Intermediate zone: $W=134$, $P>0.1$; Edge vs. Centre: $W=56, P>0.1$ ). In the inner zone of the woodlot, woody habitat species were evenly distributed in the zones logged at different periods and generalist as well as open habitat species were very scarce whatever the period of the most recent logging operation.

\section{Spatial distribution of open habitat species in the edges of the woodlot}

The species that overwintered mainly in the edges of the woodlot showed highly spatially structured distributions. S. obscuroguttatus overwintered mainly in the south-east facing edge of the woodlot, while most $A$. dor- salis overwintered in the opposite edge (Fig. 5). Carabus cancellatus Illiger and Microlestes luctuosus Holdhaus in Apfelbeck overwintered in all the edges of the woodlot except the north-east edge, while more $D$. atricapillus and Trechus quadristriatus Schrank emerged in the traps located at the north-east edge.

\section{DISCUSSION}

In the present study, we found a higher density and species richness of ground beetles overwintering in the edges than in the inner zone of the woodlot sampled. In addition, we found no effect of the date of the most recent logging operation on the density and species richness of 


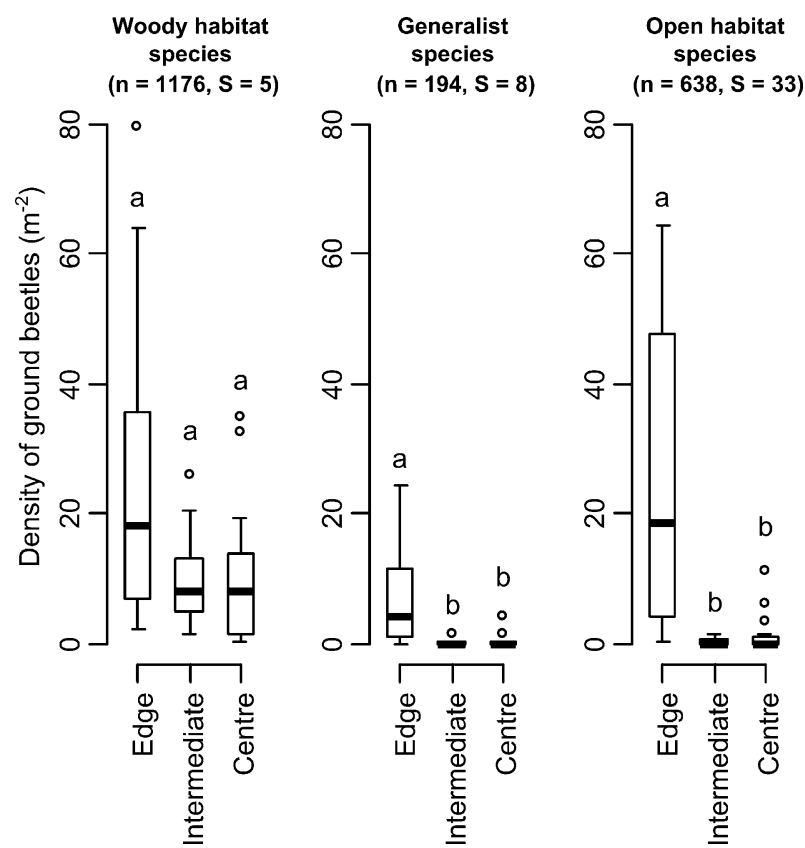

Fig. 4. Density of woody habitat, generalist and open habitat species recorded in the different zones of the woodlot based on their distance from the boundary. The number of individuals (n) and species (S) in the groups are shown above the graphs. The thick line represents the median, the limits of the boxes the $25 \%$ and the $75 \%$ quantiles and the limits of the whiskers the $10 \%$ and $90 \%$ quantiles. Outliers are plotted as dots. Different letters above the boxes indicate significant differences based on a Wilcoxon rank test including the Benjamini-Hochberg correction (P $<0.05)$.

ground beetles overwintering in the inner zone of the woodlot.

The method used in this study for trapping emerging insects has rarely been used in the past (Idinger \& Kromp,
1997; Schmidt et al., 2008). This technique has the advantage of providing population densities of all the insects that overwintered in a given place and survived the winter, whatever the overwintering stage (adults or larvae). Former studies based on quadrats (soil and litter sampling in delimited areas) note very low population densities of ground beetles in woodlands and forests. Sotherton (1984) reports a few dozen ground beetles per square metre and Geiger et al. (2009) records no ground beetles in forest. The population densities of ground beetles recorded in the present study were much higher in most of the zones, with densities of up to 140 ground beetles per square meter. Unfortunately, neither Sotherton (1984) nor Geiger et al. (2009) mention if woodland or forest samples were taken in the edge or in the inner zone of these habitats. Our study revealed major differences in the density of ground beetles in the edge and in the two inner zones of the woodlot. The density of ground beetles in the inner zone of the woodlot was low and similar to that found by Sotherton (1984). Conversely, the median density in the edges of the woodlot was five times higher than in the inner zone of the woodlot. The assemblage of species in the edges included the same species as those found in the inner zone of the woodlot plus even more species from surrounding open habitats. This could be due to the more abundant resources available in the edges than in the rest of the woodlot (Niemelä \& Spence, 1994). Concerning woody habitat species, more ground beetles overwintered in the edges than in the inner zone of the woodlot. This observation may seem surprising if the woody habitat species found at the study site were strict forest specialist species that avoid forest edges, as some species do in other regions of the world (Magura et al., 2001; Paquin, 2008). On the contrary, the woody habitat species found at the study site also colonize hedges and
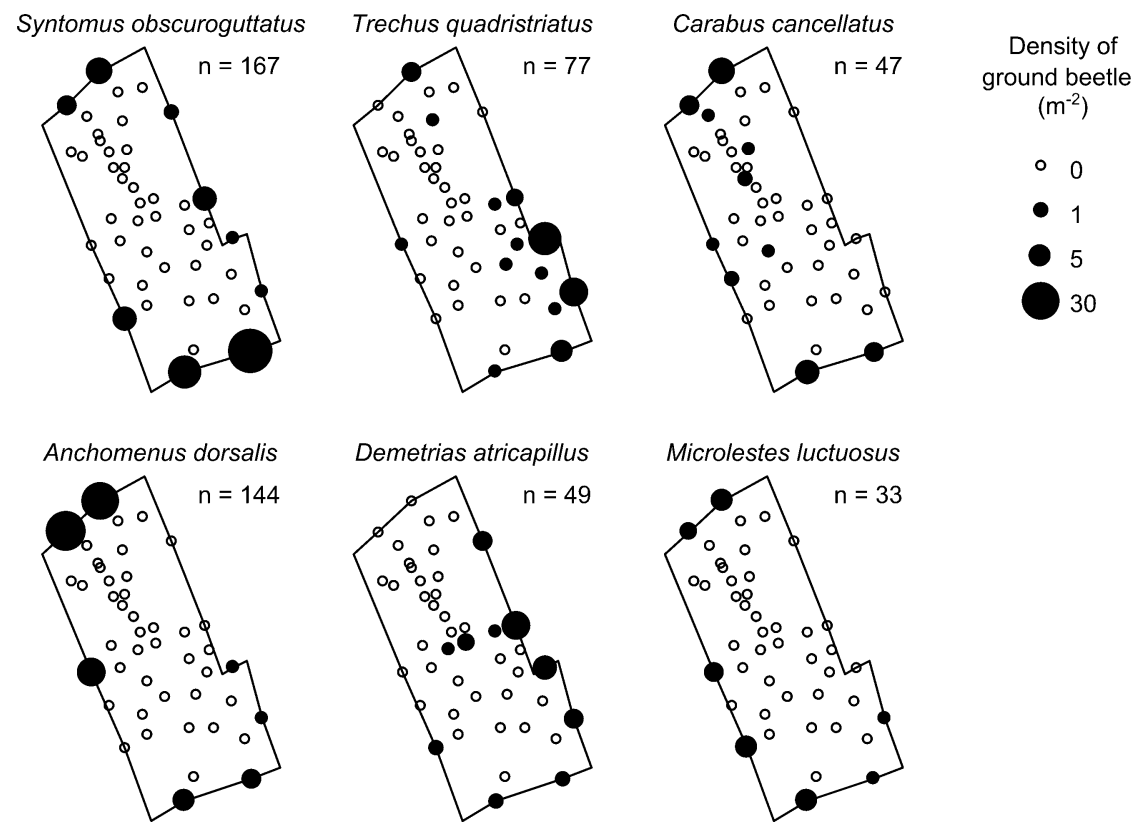

Fig. 5. Maps of the spatial distribution of the six most abundant species that were recorded mainly overwintering in the edges of the woodlot. Circles represent traps. The radius of filled circles is proportional to the cube root of the population density of ground beetles in the corresponding trap, while open circles represent traps that did not catch the species. 
some of them even move into open habitats near woodland. Thus, rather than being negatively affected by less buffered environmental conditions in the edges of the woodlot, these species could benefit from a higher habitat diversity (presence of both herbaceous plant and shrubs) as well as from more abundant and more varied food resources in the edges than in the inner zones of the woodlot (Niemelä \& Spence, 1994). In the edges of the woodlot, the population density of open habitat species of ground beetles was similar to that of woody habitat species of ground beetles. However, few or no open habitat species overwintered in the central and intermediate zones of the woodlot, which are farther than $25 \mathrm{~m}$ from the boundary. This suggests that open habitat species that enter the woodlot to overwinter do not move far into the woodlot, which accords with previous studies showing that active adults of open habitat ground beetles do not penetrate more than a few meters into woodlots (Bedford \& Usher, 1994; Magura, 2002; Baker et al., 2007). Thus open habitat ground beetles that enter woodlots to overwinter may not penetrate any farther than they do in spring and summer. Among the numerous species that overwintered only in the edges, some possibly live in this habitat. Indeed, it is thought that European woodlots and forests have become much denser with an increasingly closed canopy during the $20^{\text {th }}$ century, due to a decrease in wild ungulate populations and abandonment of ancestral practices such as pasture and coppicing in favour of even-aged stands (Rackham et al., 1998; Vera, 2000). Sparse forest stands are rare at the study site, and woodlot edges could be surrogate habitats for species preferring forests with an open canopy, as is the case for some relic species of ground beetles in sparse stands of trees in Central Europe (Spitzer et al., 2008).

The date of the most recent logging operation had no effect on any parameter characterizing the species assemblage of ground beetles within the woodlot (total density, number of species per trap, density of particular groups of species with respect to their common habitat). This was quite surprising since the soil structure of recently logged zones is disturbed and the vegetation structure is also different, which may affect the assemblage of overwintering beetles (Dennis et al., 1994; Pywell et al., 2005). In addition, a former study showed that different species assemblages of active ground beetles occurred in young stands compared to old stands of trees, with an additional influence of environmental conditions linked to forest management (du Bus de Warnaffe \& Dufrêne, 2004). In the present study, we only noted a trend to a higher density of open habitat species overwintering in zones logged between 2000 and 2003, but too few traps were placed in these zones to determine whether this trend was statistically significant. Thus it is likely that the effect of management on ground beetles in the case of coppicing with standards is much more transient than that associated with the logging of even-aged stands (du Bus de Warnaffe \& Dufrêne, 2004; Niemelä et al., 1996) since the canopy and undergrowth rapidly develop and shade the forest floor.
It is noteworthy that all the edges of the woodlot did not have the same assemblage of overwintering species. Some species were associated with particular edges, which could be the consequence of the orientation of edges, their adjacent habitat or their vegetation structure, as shown for hedges (Dennis et al., 1994).

Most of the species described in this study are potential or confirmed biocontrol agents. Species described here as woody habitat species are reported to eat large preys such as slugs (Asteraki, 1993) and many generalist and open habitat species also eat agricultural pests. For instance, Anchomenus dorsalis, Demetrias atricapillus and Trechus quadristriatus, all of which overwintered in the edges of the woodlot studied, are predators of aphids (Sotherton, 1984; Sunderland, 2002).

A better knowledge of the factors determining the distribution of these species would enable owners and farmers to manage woodlot edges so as to increase overwintering of open habitat species at these locations and thus favour their action as biocontrol agents in adjacent fields. Woodlot edges and other semi-natural habitats provide suitable overwintering refuges for different kinds of natural predators of agricultural pests. Indeed, woodlot edges may not be the most important overwintering habitat for predators (Sotherton, 1984) but could nonetheless provide shelter for particular species due to the more buffered conditions there than in other semi-natural habitats and this needs to be investigated.

ACKNOWLEDGEMENTS. We sincerely thank M. Goulard for his advice on sample stratification, S. Ladet for help with GIS, M. Redon for help in the field, C. Pelosi and reviewers for useful comments on the manuscript and D. Goodfellow for improving the English. We thank colleagues of UMR Dynafor for their technical assistance during the setting of the traps. We also gratefully acknowledge the land owners who allowed us to install emergence traps in their woodlot. This study was funded by the joint Midi-Pyrenees-Aquitaine Regions' program "Forest Biodiversity Dynamics under Global Change" and the ANRBiodiversity "BiodivAgriM" program. Anthony Roume's fellowship was granted by the French ministry of Research and Universities.

\section{REFERENCES}

ANDERSEn A. 1997: Densities of overwintering carabids and staphylinids (Col., Carabidae and Staphylinidae) in cereal and grass fields and their boundaries. J. Appl. Entomol. 121: $77-80$.

Asteraki E.J. 1993: The potential of carabid beetles to control slugs in grass/clover swards. Entomophaga 38: 193-198.

Baker S.C., Barmuta L.A., McQuillan P.B. \& Richardson A.M.M. 2007: Estimating edge effects on ground-dwelling beetles at clearfelled non-riparian stand edges in Tasmanian wet eucalypt forest. For. Ecol. Manag. 239: 92-101.

BEDFORD S.E. \& Usher M.B. 1994: Distribution of arthropod species across the margins of farm woodlands. Agr. Ecosyst. Environ. 48: 295-305.

Benjamini Y. \& Hochberg Y. 1995: Controlling the false discovery rate: a practical and powerful approach to multiple testing. 57: 289-300.

Bianchi F.J.J.A., Boolj C.J.H. \& TscharntKe T. 2006: Sustainable pest regulation in agricultural landscapes: a review on 
landscape composition, biodiversity and natural pest control. Proc. R. Soc. (B) 273: 1715-1727.

Deconchat M. 2001: Effets des techniques d'exploitation forestière sur l'état de surface du sol. Ann. For. Sci. 58: 653-661.

Dennis P., Thomas M.B. \& Sotherton N.W. 1994: Structural features of field boundaries which influence the overwintering densities of beneficial arthropod predators. J. Appl. Ecol. 31: 361-370.

Du Bus de Warnaffe G. \& Dufrêne M. 2004: To what extent can management variables explain species assemblages? A study of carabid beetles in forests. Ecography 27: 701-714.

du Bus de Warnaffe G., Deconchat M., Ladet S. \& Balent G. 2006: Variability of cutting regimes in small private woodlots of south-western France. Ann. For. Sci. 63: 915-927.

Geiger F., Wackers F. \& Bianchi F.J.J.A. 2009: Hibernation of predatory arthropods in semi-natural habitats. BioControl 54: 529-535.

Honek A., Martinkova Z. \& Jarosik V. 2003: Ground beetles (Carabidae) as seed predators. Eur. J. Entomol. 100: 531-544.

HURKa K. 1996: Carabidae of the Czech and Slovak Republics. Kabourek, Zlin, 565 pp.

IDINGER J. \& KROMP B. 1997: Ground photoeclector evaluation of different arthropod groups in unfertilized, inorganic and compost-fertilized cereal fields in eastern Austria. Biol. Agric. Hortic. 15: 171-176.

Jeannel R. 1942: Coléoptères carabiques, I and II. Fédération Française des Sociétés de Sciences Naturelles, Paris, 1171 pp.

Jukes M.R., Peace A.J. \& Ferris R. 2001: Carabid beetle communities associated with coniferous plantations in Britain: the influence of site, ground vegetation and stand structure. For. Ecol. Manag. 148: 271-286.

Kromp B. 1999: Carabid beetles in sustainable agriculture: a review on pest control efficacy, cultivation impacts and enhancement. Agric. Ecosyst. Environ. 74: 187-228.

LANDIS D.A., WratTen S.D. \& GurR G.M. 2000: Habitat management to conserve natural enemies of arthropod pests in agriculture. Annu. Rev. Entomol. 45: 175-201.

LuFF M.L. 2002: Carabid assemblage organization and species composition. In Holland J.M. (ed.): The Agroecology of Carabid Beetles. Intercept, Andover, pp. 41-79.

Magura T. 2002: Carabids and forest edge: spatial pattern and edge effect. For. Ecol. Manag. 157: 23-37.

Magura T., Tóthmérész B. \& Mólnar T. 2001: Forest edge and diversity: carabids along forest-grassland transetcs. Biodivers. Conserv. 10: 287-300.

MurCia C. 1995: Edge effects in fragmented forests - implications for conservation. Trends Ecol. Evol. 10: 58-62.

Niemelä J.K. \& SPence J.R. 1994: Distribution of forest dwelling carabids (Coleoptera) - spatial scale and the concept of communities. Ecography 17: 166-175.

Niemelä J., Haila Y. \& Puntilla P. 1996: The importance of small-scale heterogeneity in boreal forests: variation in diversity in forest-floor invertebrates across the succession gradient. Ecography 19: 352-368.
Paquin P. 2008: Carabid beetle (Coleoptera: Carabidae) diversity in the black spruce succession of eastern Canada. Biol. Conserv. 141: 261-275.

PfiFfner L. \& LuKA H. 2000: Overwintering of arthropods in soils of arable fields and adjacent semi-natural habitats. Agric. Ecosyt. Environ. 78: 215-222.

Pizzolotto R., Brandmayr P. \& Mazzei A. 2005: Carabid beetles in a mediterranean region: biogeographical and ecological features. In Lövei G.L. \& Toft S. (eds): Proceedings of the 11th European Carabidologists' Meeting, 21 July 2003 - 24 July 2003, Arhus. Danish Institute of Agricultural Sciences, Tjele, pp. 244-254.

Pywell R.F., James K.L., Herbert I., Meek W.R., Carvell C., Bell D. \& Sparks T.H. 2005: Determinants of overwintering habitat quality for beetles and spiders on arable farmland. Biol. Conserv. 123: 79-90.

RACKHAM O. 1998: Savanna in Europe. In Kirby K.J. \& Watkins C. (eds): The Ecological History of European Forests. CAB International, Wallingford, pp. 1-24.

R Development Core Team 2010: $R$ Foundation for Statistical Computing. Vienna.

Schmidt M.H., Rocker S., Hanafi J. \& Gigon A. 2008: Rotational fallows as overwintering habitat for grassland arthropods: the case of spiders in fen meadows. Biodivers. Conserv. 17: 3003-3012.

Sotherton N.W. 1984: The distribution and abundance of predatory arthropods overwintering on farmland. Ann. Appl. Biol. 105: 423-429.

Spitzer L., Konvicka M., Benes J., Tropek R., Tuf I.H. \& Tufova J. 2008: Does closure of traditionally managed open woodlands threaten epigeic invertebrates? Effects of coppicing and high deer densities. Biol. Conser. 141: 827-837.

SUNDERLAND K.D. 2002: Invertebrate pest control by carabids. In Holland J.M. (ed.): The Agroecology of Carabid Beetles. Intercept, Andover, pp. 165-214.

Symondson W.O.C., Sunderland K.D. \& Greenstone M.H. 2002: Can generalist predators be effective biocontrol agents? Annu. Rev. Entomol. 47: 561-594.

Thiele H.U. 1977: Carabid Beetles in their Environments. Springer, Berlin, 369 pp.

Thomas M.B., Wratten S.D. \& Sotherton N.W. 1992: Creation of island habitats in farmland to manipulate populations of beneficial arthropods - predator densities and species composition. J. Appl. Ecol. 29: 524-531.

Tooley J. \& BRUST G.E. 2002: Weed seed predation by carabid beetles. In Holland J.M. (ed.): The Agroecology of Carabid Beetles. Intercept, Andover, pp. 215-229.

VERA F.W.M. 2000: Grazing Ecology and Forest History. CAB International, Wallingford, $506 \mathrm{pp}$.

Yamazaki K., Sugiura S. \& Kawamura K. 2002: Environmental factors affecting the overwintering distribution of ground beetles (Coleoptera: Carabidae) on a forest floor in central Japan. Entomol. Sci. 5: 125-130.

Received January 17, 2011; revised and accepted May 9, 2011

APPENDIX 1. Habitats in which adults of the trapped species are known to occur between spring and autumn together with the numbers caught (abundance) in this study. w, woody habitat; g, generalist; o, open habitat species; -, not known.

\begin{tabular}{lccc}
\hline Species & Code & Habitat & Abundance \\
\hline Abax parallelepipedus Piller \& Mitterpacher & abapar & w & 478 \\
Acinopus picipes Olivier & acipic & o & 1 \\
Acupalpus brunnipes Sturm & acubru & - & 2 \\
Acupalpus meridianus Linnaeus & acumer & o & 1 \\
Agonum muelleri Herbst & agomue & o & 1 \\
Amara eurynota Panzer & amaeur & & 1
\end{tabular}


Amara familiaris Duftschmid

Amara lucida Duftschmid

Amara ovata Fabricius

Amara similata Gyllenhal

Amblystomus niger Heer

Anchomenus dorsalis Pontoppidan

Brachinus crepitans Linnaeus

Brachinus elegans Chaudoir

Brachinus explodens Duftschmid

Brachinus sclopeta Fabricius

Bradycellus verbasci Duftschmid

Calodromius bifasciatus Dejean

Calathus fuscipes Goeze

Carabus auratus Linnaeus

Carabus cancellatus Illiger

Carabus nemoralis O.F. Müller

Carabus violaceus purpurascens Fabricius

Clivina fossor Linnaeus

Demetrias atricapillus Linnaeus

Diachromus germanus Linnaeus

Gynandromorphus etruscus Quensel in Schönherr

Harpalus dimidiatus P. Rossi

Metallina lampros Herbst

Microlestes luctuosus Holdhaus in Apfelbeck

Microlestes negrita Wollaston

Nebria brevicollis Fabricius

Nebria salina Fairmaire \& Laboulbène

Notiophilus quadripunctatus Dejean

Notiophilus rufipes Curtis

Olisthopus sturmii Duftschmid

Ophonus sabulicola Panzer

Parophonus mendax P. Rossi

Phyla obtusa Audinet-Serville

Poecilus cupreus Linnaeus

Polistichus connexus Geoffroy in Fourcroy

Pseudoophonus rufipes De Geer

Pterostichus madidus Fabricius

Stenolophus teutonus Schrank

Stomis pumicatus Panzer

Syntomus obscuroguttatus Duftschmid

Trechus quadristriatus Schrank

Zuphium olens P. Rossi

\begin{tabular}{|c|c|c|}
\hline amafam & o & 3 \\
\hline amaluc & o & 2 \\
\hline amaova & o & 5 \\
\hline amasim & o & 19 \\
\hline ambnig & - & 2 \\
\hline ancdor & o & 144 \\
\hline bracre & o & 9 \\
\hline braele & o & 14 \\
\hline braexp & o & 2 \\
\hline brascl & o & 11 \\
\hline braver & o & 6 \\
\hline calbif & o & 2 \\
\hline calfus & o & 1 \\
\hline caraur & w & 209 \\
\hline carcan & o & 47 \\
\hline carnem & $\mathrm{w}$ & 78 \\
\hline carpur & $\mathrm{g}$ & 58 \\
\hline clifos & o & 1 \\
\hline dematr & o & 49 \\
\hline diager & o & 69 \\
\hline gynetr & o & 3 \\
\hline hardim & o & 18 \\
\hline metlam & o & 1 \\
\hline micluc & o & 33 \\
\hline micneg & o & 1 \\
\hline nebbre & $\mathrm{g}$ & 26 \\
\hline nebsal & - & 3 \\
\hline notqua & - & 4 \\
\hline notruf & $\mathrm{w}$ & 1 \\
\hline olistu & - & 1 \\
\hline ophsab & o & 2 \\
\hline parmen & $\mathrm{g}$ & 20 \\
\hline phyobt & - & 2 \\
\hline poecup & o & 5 \\
\hline polcon & - & 1 \\
\hline pseruf & o & 17 \\
\hline ptemad & $\mathrm{w}$ & 410 \\
\hline steteu & - & 5 \\
\hline stopum & o & 1 \\
\hline synobs & o & 167 \\
\hline trequa & $\mathrm{g}$ & 77 \\
\hline zupole & o & 1 \\
\hline
\end{tabular}

